SUSTAINABLE FORESTRY

COLLECTION 81-82, 2020
ODRŽIVO ŠUMARSTVO

ZBORNIK RADOVA 81-82, 2020

UDK $630 * 232.12: 582.475=111$

Original scientific paper

\title{
VARIABILITY OF POTASSIUM CONTENT IN THE NEEDLES OF DOUGLAS-FIR PROVENANCES OF CANADIAN ORIGIN
}

\author{
Filip JOVANOVIĆ ${ }^{l}$, Vera LAVADINOVIĆl , Ljubinko RAKONJAC ${ }^{l}$, \\ Snežana STAJIĆ ${ }^{l}$, Zoran MILETIĆ ${ }^{l}$
}

\begin{abstract}
The provenance test model is based on the analysis of growth, anatomical, physiological, chemical, mechanical, and other properties of an allochthonous species to justify its transfer from the place of origin to new ecosystems. Douglas-fir is one of the most common allochthonous conifer species in the forest plantations of Europe. Given that the analysis of different physiological properties of trees is important for the introduction of specified provenances into new habitats, this paper presents the results of an investigation of the variability of potassium content in young Douglas-fir needles of 14 Canadian provenances raised on two experimental sites in Belgrade. Potassium is an essential element involved in a number of biochemical and physiological processes and plays a significant role in the adaptation of plants on biotic and abiotic stress factors. Determination of the deviation of potassium content in the needles of each Douglas-fir provenance studied was performed using the Z-test.
\end{abstract}

Keywords: Douglas-fir, provenance, introduction, potassium, Serbia

\section{VARIJABILNOST SADRŽAJA KALIJUMA U ČETINAMA KANADSKIH PROVENIJENCIJA DUGLAZIJE}

Izvod: Model provenijeničnog testa zasniva se na analizama rasta, anatomskih, fizioloških, hemijskih, mehaničkih, kao i drugih osobina alohtone vrste, s ciljem provere opravdanosti njene introducije iz zemlje porekla u nove ekosisteme. Duglazija je jedna od najčešće gajenih alohtonih vrsta četinara u plantažama $i$ šumskim kulturama Evrope. Kako

\footnotetext{
${ }^{1}$ Dr Filip Jovanović, Dr Vera Lavadinović, Dr Ljubinko Rakonjac, Dr Snežana Stajić, Dr Zoran Miletić, Institute of Forestry, 3 Kneza Višeslava, 11030 Belgrade, Serbia.

Author for correspondence: Dr Filip Jovanović, Institute of Forestry, 3 Kneza Višeslava, 11030 Belgrade, Serbia, +381628838006, e-mail: filip.a.jovanovic@gmail.com
} 
je analiza različitih fizioloških svojstava drvenastih vrsta od značaja pri introdukciji provenijencija u nova staništa, u radu su predstavljeni rezultati istraživanja varijabilnosti sadržaja kalijuma u mladim četinama 14 kanadskih provenijencija duglazije gajenih na dva eksperimentalna polja u Beogradu. Kalijum je esencijalni element koji učestvuje u nizu biohemijskih i fizioloških procesa i ima značajnu ulogu pri adaptaciji biljaka u uslovima biotičkog $i$ abiotičkog stresa. Odstupanje sadržaja kalijuma u četinama svake ispitivane provenijencije određeno je Z-testom.

Ključne reči: duglazija, provenijencije, introdukcija, kalijum, Srbija

\section{INTRODUCTION}

Douglas-fir [Pseudotsuga menziesii (Mirb.) Franco, fam. Pinaceae] is a very tall and fast-growing conifer species native to North America. Under optimal conditions, this species reaches a height of over $100 \mathrm{~m}$, a diameter of $4 \mathrm{~m}$, and an age of 1,300 years or more. Its wide geographical range in terms of latitude (from central British Columbia to the mountains of central Mexico), longitude (from New Mexico to Vancouver) and altitude (from $0 \mathrm{~m}$ a. s. 1. to 3,000 $\mathrm{m}$ a. s. 1.) (Hermann, Lavender, 1990) has produced a number of provenances. At the present time, due to its economic importance and the assumption that it can resist climate change, Douglas-fir is an integral part of forest management in many European countries (Lavender and Hermann, 2014). It is the second most abundant species in European forests, covering more than 800,000 ha (Spiecker et al., 2019).

Being a highly productive introduced species, not only in Europe but also in the world, Douglas-fir was a subject of numerous studies and a topic of many scientific conferences. Based on the studies conducted in North America (e.g., Herman and Lavender, 1987, 1990), and the provenance trials of this species in Europe (e.g., Da Ronch et al., 2016; Spiecker et al., 2019), detailed knowledge of the genetic potential of Douglas-fir provenances has been acquired. In Serbia, the study and testing of Douglas-fir provenances from North America have begun in 1978 at the Institute of Forestry, Belgrade, and continued by setting up provenance trials on several sites (e.g., Lavadinović, 1995; Lavadinović and Koprivica, 1996, 1999, 2000; Lavadinović and Isajev, 2005; Lavadinović, 2009). The trials of the introduced Douglas-fir provenances of Canadian origin have been performed by laboratory analysis of seed germination, measurement of tray plants, determination of survival percentage of seedling nursery plants, the establishment of experimental plots, and long-term measurement of plant taxation elements (Popović et al., 2013).

The main reason for the establishment of a provenance test is to determine the economic justification for the introduction of new species and to assess the risk arising from the transfer of their seeds from the area of origin to new ecological conditions. The introduction must involve only those species that attain the maximum production qualities and economic effectiveness in the natural area (Popović et al., 2013). Consequently, the provenance test model is usually based on the analysis of growth, anatomical, physiological, chemical, mechanical, and other properties of an allochthonous species. Since the analysis of different physiological properties of trees is important for the introduction of specified provenances to new habitats, several papers have been published on the subject of nutrient content in 
the needles of Douglas-fir provenances raised in Serbia (Lavadinović et al., 2012, 2014, 2015, 2018, 2019). As a contribution to the study of nutrition in Douglas-fir provenances, this paper presents an analysis of the variability of potassium content in the needles of Douglas-fir provenances, originating from a number of Canadian sites of different geographical latitudes and longitudes, and altitudes.

Potassium has considerable importance in the physiological processes of plants. As a biogenic macronutrient, potassium activates more than 50 enzymes, and as a cofactor, it participates in a series of enzymatic reactions that take place in photosynthesis, respiration, and other processes. Potassium plays a significant role in the neutralization of excess organic acids in cells, hydration of colloids of protoplasm, osmoregulation, as well as in the mechanism of opening and closing stomatal pores. It is an important nutrient in the processes of synthesis, transport, and accumulation of carbohydrates and it increases resistance to drought and other stress factors (low temperatures, salts, diseases, air pollution, etc.). Potassium plays a significant role in the regulation of active transport across cell membranes and the uptake of other essential elements, as well as in the protection against oxidative stress because it regulates the activity of enzymes involved in the detoxification of reactive oxygen (Wang et al., 2013).

\section{MATERIAL AND METHODS}

The present study is based on an analysis of the variability of potassium content in young needles of different Douglas-fir provenances. The study included 14 Douglas-fir provenances of Canadian origin of latitude ranging from $49^{\circ} 10^{\prime}$ to $51^{\circ} 35^{\prime}$, longitude from $115^{\circ} 20^{\prime}$ to $120^{\circ} 10^{\prime}$, altitude from 105 to $1,070 \mathrm{~m}$ (Table 1).

Table 1. The origin of the analyzed Douglas-fir provenances

\begin{tabular}{|c|c|c|c|c|c|}
\hline $\begin{array}{c}\text { Provenance } \\
\text { code }\end{array}$ & Mark & Locality & Latitude & Longitude & $\begin{array}{c}\text { Altitude } \\
(\mathrm{m})\end{array}$ \\
\hline 03333 & 1 & Cranbrook & $49^{\circ} 25^{\prime}$ & $115^{\circ} 20^{\prime}$ & 105 \\
\hline 00848 & 2 & Inonoaklin & $49^{\circ} 50^{\prime}$ & $118^{\circ} 10^{\prime}$ & 671 \\
\hline 30667 & 3 & Mann Creek & $51^{\circ} 35^{\prime}$ & $120^{\circ} 10^{\prime}$ & 600 \\
\hline 05227 & 4 & Gavia Lake & $50^{\circ} 56^{\prime}$ & $116^{\circ} 35^{\prime}$ & 1,070 \\
\hline 05226 & 5 & Nine Bay & $50^{\circ} 58^{\prime}$ & $115^{\circ} 32^{\prime}$ & 975 \\
\hline 03356 & 6 & Trout Creek & $49^{\circ} 40^{\prime}$ & $119^{\circ} 52^{\prime}$ & 684 \\
\hline 03360 & 7 & Michell Creek & $49^{\circ} 54^{\prime}$ & $119^{\circ} 37^{\prime}$ & 1,035 \\
\hline 01198 & 8 & Salmo & $49^{\circ} 15^{\prime}$ & $117^{\circ} 30^{\prime}$ & 793 \\
\hline 30460 & 9 & Mara Lake & $50^{\circ} 48^{\prime}$ & $119^{\circ} 00^{\prime}$ & 188 \\
\hline 00278 & 10 & Monte Creek & $50^{\circ} 37^{\prime}$ & $119^{\circ} 52^{\prime}$ & 701 \\
\hline 03383 & 11 & Sheep Creek & $49^{\circ} 10^{\prime}$ & $117^{\circ} 15^{\prime}$ & 1,000 \\
\hline 30461 & 12 & Cooke Creek & $50^{\circ} 38^{\prime}$ & $118^{\circ} 49^{\prime}$ & 900 \\
\hline 03389 & 13 & Benton Creek & $49^{\circ} 12^{\prime}$ & $117^{\circ} 25^{\prime}$ & 933 \\
\hline 05092 & 14 & Sun Creek & $50^{\circ} 08^{\prime}$ & $115^{\circ} 52^{\prime}$ & 1,000 \\
\hline
\end{tabular}

The provenance trials were set up on two sites in Belgrade, Serbia. In the Arboretum of the Faculty of Forestry (44⒋ $\left.46^{\prime} 59.8^{\prime \prime N}, 20^{\circ} 25^{\prime} 37.9^{\prime \prime} \mathrm{E}\right)$, the soil type was eutric cambisol, while in the Sremčica nursery (44⒋ $\left.41^{\prime} 07.7^{\prime \prime} \mathrm{N}, 20^{\circ} 22^{\prime} 08.7^{\prime \prime E}\right)$, it was vertisol. The seedlings were produced in containers, and at the age of 3 years they were transplanted into experimental plots with a distance of $2 \times 2 \mathrm{~m}$ (60 plants from each provenance). On the sites where the analyzed trees had been established, 
the microclimate conditions were relatively similar. The relief was flat (with no prominent exposures) and the altitudes were approximately the same. All analyzed individuals were of 12 years of age.

For the analysis of potassium content in different Douglas-fir provenances, the one-year-old needles from the top third of the tree crowns were sampled and analyzed. The needles were dried to the absolutely dry state at $550^{\circ} \mathrm{C}$ and grounded to a fine powder. The potassium content was determined by the ash analysis, after conversion to chlorides, using the complexometric determination technique.

The deviation of potassium content in the needles of each Douglas-fir provenance was determined by the Z-test, according to the following formula:

$$
\mathrm{Z}=(\overline{\mathrm{X}}-\mathrm{x}) / \sigma
$$

where $\bar{X}$ is the mean value of potassium content in the needles of all provenances; $\mathrm{x}$ is the potassium content in each provenance; $\sigma$ is the standard deviation of potassium content in the needles.

All obtained numerical data were analyzed using the statistical software STATISTICA (StatSoft Inc., Tulsa, OK, 1997).

\section{RESULTS AND DISCUSSION}

The results of the analysis of variability of potassium content in the needles of 14 Canadian Douglas-fir provenances, raised on two experimental sites and two soil types in Belgrade, are presented in Table 2 and Graph 1.

Table 2. Statistical analysis of potassium content in young needles of 14 Canadian Douglas-fir provenances raised on two experimental sites and two soil types in Belgrade, Republic of Serbia

\begin{tabular}{|c|c|c|c|c|c|c|}
\hline \multicolumn{3}{|c|}{ Provenance } & \multicolumn{2}{|c|}{$\begin{array}{l}\text { Sremčica } \\
\text { (Vertisol) }\end{array}$} & \multicolumn{2}{|c|}{$\begin{array}{c}\text { Arboretum } \\
\text { (Eutric cambisol) }\end{array}$} \\
\hline Mark & Code & Origin & $\begin{array}{c}\mathbf{K} \\
(\%)\end{array}$ & $\mathbf{Z}$ & $\begin{array}{c}\mathbf{K} \\
(\%)\end{array}$ & $\mathbf{Z}$ \\
\hline 1 & 03333 & Cranbrook & 0.78 & -0.5860 & 0.75 & -0.3812 \\
\hline 2 & 00848 & Inonoaklin & 0.77 & -0.4781 & 0.90 & -1.8250 \\
\hline 3 & 30667 & Mann Creek & 0.61 & 0.9922 & 0.86 & -1.4351 \\
\hline 4 & 05227 & Gavia Lake & 0.77 & -0.5050 & 0.56 & 1.5199 \\
\hline 5 & 05226 & Nine Bay & 0.68 & 0.3521 & 0.82 & -0.9981 \\
\hline 6 & 03356 & Trout Creek & 0.65 & 0.6496 & 0.59 & 1.1885 \\
\hline 7 & 03360 & Michell Creek & 0.80 & -0.8564 & 0.75 & -0.3015 \\
\hline 8 & 01198 & Salmo & 0.76 & -0.4698 & 0.65 & 0.6235 \\
\hline 9 & 30460 & Mara Lake & 0.81 & -0.9392 & 0.67 & 0.4028 \\
\hline 10 & 00278 & Monte Creek & 0.56 & 1.4722 & 0.57 & 1.4364 \\
\hline 11 & 03383 & Sheep Creek & 0.53 & 1.7582 & 0.65 & 0.6011 \\
\hline 12 & 30461 & Cooke Creek & 0.84 & -1.2236 & 0.74 & -0.2362 \\
\hline 13 & 03389 & Benton Creek & 0.66 & 0.5689 & 0.74 & -0.2106 \\
\hline 14 & 05092 & Sun Creek & 0.68 & 0.3565 & 0.87 & -1.4761 \\
\hline & & Mean & 0.71 & & 0.72 & \\
\hline & & $\mathbf{S}$ & 0.0965 & & 0.1130 & \\
\hline & & Min. & 0.53 & & 0.56 & \\
\hline & & Max. & 0.84 & & 0.90 & \\
\hline
\end{tabular}

Based on the results obtained, the mean value of potassium content in the needles of the Douglas-fir provenances raised on eutric cambisol is $0.71 \%$. The maximum value of potassium content $(0.84 \%)$ was determined in the provenance 
12, originating from Cooke Creek (provenance code 30461), while the minimum value $(0.53 \%)$ was determined in the provenance 11, originating from Sheep Creek (code 03383).

The mean, maximum and minimum values of potassium content in the needles of the Douglas-fir provenances raised on vertisol were approximate to the values determined for the provenances raised on eutric cambisol. The mean value of potassium content in the needles of the provenances raised on vertisol is $0.72 \%$. The maximum uptake of potassium $(0.90 \%)$ was detected in the provenance 2 , originating from Inonoaklin (code 00848), while the minimum amount $(0.56 \%)$ of potassium has been absorbed by the provenance 4 from Gavia Lake (code 05227).

Although all analyzed trees had been raised under the same site and stand conditions (soil type and local climate), the high variability of potassium content between the provenances on both sites (and soil types) was detected. The existence of differences in the concentrations of particular chemical elements in provenances may indicate their peculiarity in the adsorption of these elements (Lavadinović et al., 2019). Since all environmental conditions that have a significant impact on physiological processes in plants (including uptake of nutrients) had been relatively identical on the experimental sites, the detected variability was arguably a result of the genetic traits of the analyzed provenances, i.e., their ability to exploit the soil potentials in terms of potassium uptake.

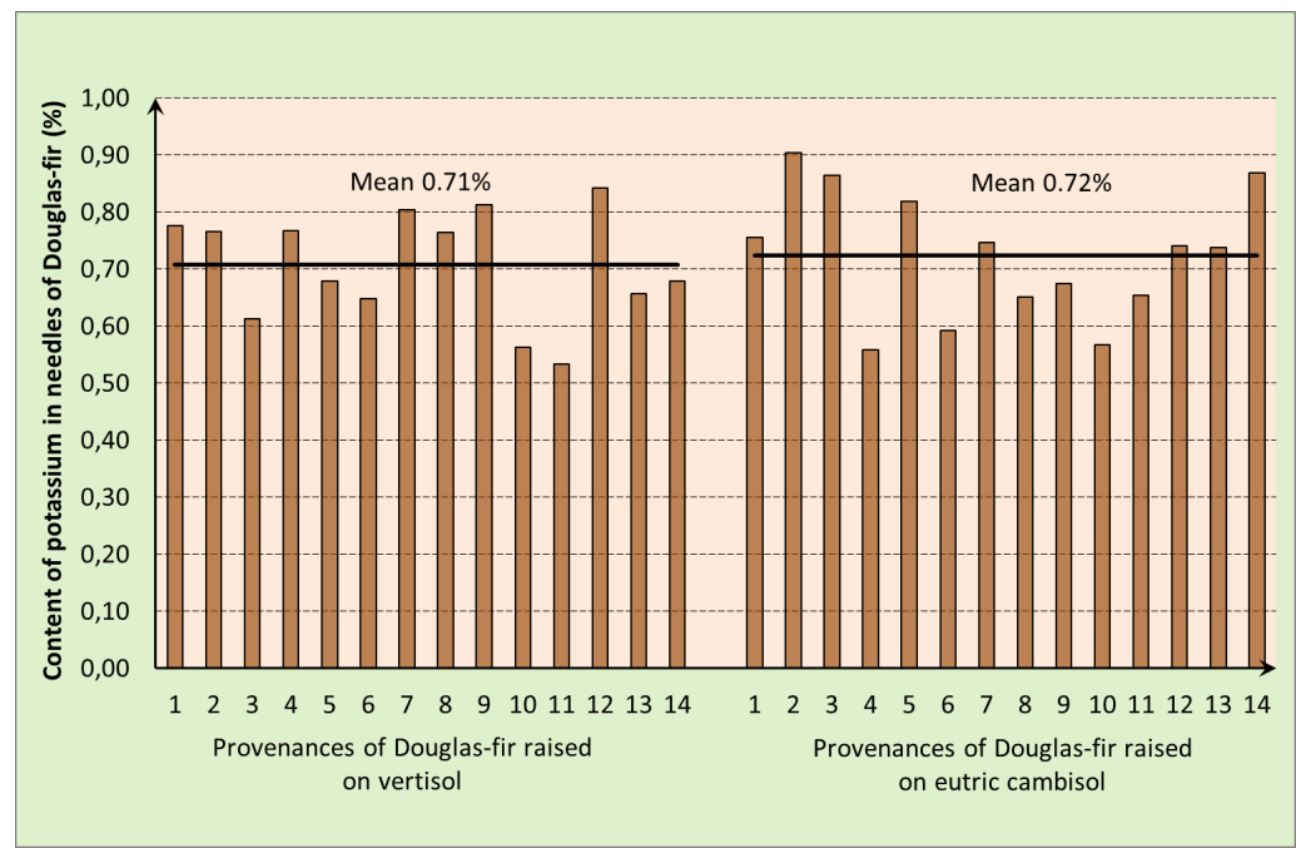

Graph 1. Variability of potassium content in the needles of 14 Canadian Douglasfir provenances raised on two experimental sites and two soil types in Belgrade

On both sites, the provenances 1, 2, 7 and 12 (from Cranbrook, Inonoaklin, Michell Creek and Cooke Creek, respectively) had high potassium content as compared to the mean value of potassium content determined for all provenances 
$(0.72 \%)$. In contrast, on both sites, lower potassium content than the stated mean value was detected in the provenances 6,10 and 11 (from Trout Creek, Monte Creek and Sheep Creek, respectively). On vertisol, the provenances 4, 8 and 9 (from Gavia Lake, Salmo and Mara Lake, respectively) had higher potassium content than the stated mean value, but this was not the case on eutric cambisol. On eutric cambisol, in comparison to the stated mean value, high potassium content was detected in the provenances 3, 5, 13 and 14 (from Mann Creek, Nine Bay, Benton Creek and Sun Creek, respectively) while on vertisol the same provenances had lower potassium content than the stated mean value.

The presented results are comparable with those published in the literature. The potassium content in the needles of Douglas-fir provenances examined by Lavadinović et al. (2019) ranged from $0.83 \%$ to $1.40 \%$, and the mean value was $1.03 \%$. The highest amount of potassium has been found in the provenance marked as "Oregon 205-14", the only provenance with potassium content that significantly deviated from the mean value (Lavadinović et al., 2019). According to ĐunisijevićBojović (2019), the potassium content in leaves usually ranges from $0.75 \%$ to $2.5 \%$ and plants are considered to be exposed to an acute deficiency if the potassium content is below $0.6 \%$. Therefore, it can be stated that on both experimental sites the Canadian Douglas-fir provenances 1, 2 and 7 had normal potassium content in the needles, while the Douglas-fir provenances 10 and 13 were low or deficient in potassium as compared to the literature data. The remaining provenances analyzed had normal, low or deficient potassium content in their needles depending on the site and soil type they were raised on. In contrast to previous research regarding the content of $\mathrm{Ca}, \mathrm{Mg}, \mathrm{P}, \mathrm{C}, \mathrm{N}$ in the needles of 14 Canadian Douglas-fir provenances tested on the same experimental sites (Lavadinović et al., 2012, 2014, 2015, 2018), in the present study, there are no significant differences in the uptake of potassium between the provenances raised on vertisol and those raised on eutric cambisol.

The amount of potassium in plant tissue depends on the species, organ and age of the plant (Nešković et al., 2003; Oljača et al., 2006). Since the differences in the contents of particular chemical elements in provenances may indicate their peculiarities in the adsorption of these elements, it may be argued that among the 14 Canadian Douglas-fir provenances analyzed, the provenances 1, 2 and 7 have superior potassium absorption and accumulation capacity. Further studies should determine whether there are positive correlations between potassium adsorption and other provenance properties (physiological vitality and resistance to diseases, drought, low temperatures, air pollution, as well as other environmental stressors). According to Lavender and Hermann (2014), the availability of chemical elements is one of the factors that affect the resistance of Douglas-fir to frost. For instance, Alden (1971) stated that, in populations in which potassium and nitrogen were deficient, trees were significantly less resistant to cold during the acclimatization period than trees in populations that had a surplus of these elements. However, Larsen (1978) hypothesized that the better survival of winter conditions, observed in Douglas-fir with sufficient amounts of potassium in tissues, was not due to the higher resistance to frost but to drought in the frost period. Larsen (1983) studied the effect of nitrogen and potassium supply on drought resistance in 2-year-old Douglas-fir seedlings from Snoqualmie (Washington), which were grown under experimental conditions and treated by 11 different supply levels of these nutrients. 
He found that potassium had a positive effect on drought resistance in the tested plants. On the other hand, the experiment by Timmis (1974), performed on oneyear-old Douglas-fir seedlings from the Pacific coast, showed that seedlings free of nitrogen but rich in phosphorus and potassium were not cold-resistant enough to survive winter conditions even in their natural habitats. The results of this study indicate that the frost resistance of the analyzed plants is more dependent on the relationship between the mineral nutrients than on the availability of an individual nutrient.

The antagonism between potassium and $\mathrm{Na}^{+}, \mathrm{NH}_{4}{ }^{+}, \mathrm{Ca}_{2}{ }^{+}, \mathrm{Mg}_{2}{ }^{+}$has been observed so far, thus their relationship in the nutrient environment is extremely important from the point of view of the mineral nutrition in plants (Ingestad, 1973). The importance of potassium in plant metabolism is indicated by the fact plants absorb it most intensively in the earliest stages of their development. Furthermore, with the increase of the potassium content, the uptake of $\mathrm{CO}_{2}$ and the synthesis of carbohydrates and proteins also increase in plants, while in its absence the process of photosynthesis slows down and the respiration becomes more intense (Nešković et al., 2003; Oljača et al., 2006). Since a good supply of basic biogenic elements prevents the occurrence of chlorosis in the post-transplant period and affects better survival, physiological vitality, and further plant growth and development (Đukić et al., 2004), the inclusion of essential nutrients in nutrition is the most effective method for improving quality and biomass production of seedlings and forest trees, and it can be used to significantly shorten the rotation period (Ingestad, 1973).

\section{CONCLUSIONS}

Based on the results of the analysis of potassium content variability in the needles of 14 Canadian Douglas-fir provenances, raised on two experimental sites and two soil types in Belgrade, it can be concluded that there were no significant differences in the uptake of this element between the provenances raised on vertisol and those raised on eutric cambisol. The mean, maximum and minimum values of potassium content in young needles of the provenances raised on vertisol were approximate to the values of potassium content determined for the provenances raised on eutric cambisol.

In comparison to literature data, it can be stated that on both experimental sites the Douglas-fir provenances 1, 2 and 7 had normal potassium contents, while the provenances 10 and 13 were low or deficient in this nutrient. The remaining provenances analyzed had normal, low or deficient content of potassium in their needles depending on the site and soil type they were raised on.

Given that all environmental conditions that have a significant impact on nutrient uptake in plants had been similar on both experimental sites, it may be argued that the detected variability was a result of the genetic traits of the analyzed provenances. On both experimental sites, the highest potassium content was found in the provenances 1,2 and 7 , so they may represent superior provenances for the uptake and accumulation of this nutrient.

These findings have practical significance because the potassium content in Douglas-fir tissues is one of the factors that affect its resistance to stress factors (such as cold and drought) and it could determine the future selective application of 
suitable provenances for certain habitats in forestry practice. Further studies should show whether there are positive correlations between potassium content and other provenance properties (e.g., physiological vitality and resistance to diseases).

\section{REFERENCES}

Alden, J. N. (1971): Freezing resistance of tissues in the twig of Douglas-fir (Pseudotsuga menziesii (Mirb.) Franco). PhD Thesis. Oregon State University. Corvallis

Da Ronch, F., Caudullo, G. and De Rigo, D. (2016): Pseudotsuga menziesii in Europe: distribution, habitat, usage and threats. In: Jesus San-Miguel-Ayanz, Daniele de Rigo, Giovanni Caudullo, Tracy Houston Durrant and Achille Mauri (eds.). European atlas of forest tree species. Publication Office of the European Union. Luxembourg. 146-147

Đukić, M., Đunisijević, D., Grbić, M. and Skočajić, D. (2004): Influence of nutrition and various substrates on spruce seedling growth, Bulletin of the Faculty of Forestry, 89: 103113

Đunisijević-Bojović, D. (2019): Plant ecophysiology - Practicum. University of Belgrade Faculty of Forestry. Belgrade (In original: Dunisijević-Bojović, D. (2019): Ekofiziologija biljaka - Praktikum. Univerzitet u Beogradu - Šumarski fakultet. Beograd)

Hermann, R. and Lavender, D. (1987): North American tree species in Europe, Journal of Forestry, 85(12): 27-32

Herman, R. and Lavender, D. (1990): Pseudotsuga menziesii (Mirb.) Franco: Douglas-fir. In: Russell M. Burn and Barbara H. Honkala (coords). Silvics of North America Volume 1: Conifers. USDA Forest Service. 527-540

Ingestad, T. (1973): Comparison of nutrient properties in forest tree species, Cen. an Tree inpr., Stockholm, 5(9): 5-9

Larsen, J. B. (1978): Die Frostresistenz von 60 verschiedenen Douglasienherkünften sowie über den Einfluss der Nährstoffversorgung auf die Frostresistenz der Douglasie. Schriftenreihe aus der Forstlichen Fakultät der Universitat Göttingen. Göttingen

Larsen, J. B. (1983): Trockenresistenz, Wasserhaushalt und Wachstum junger Douglasien (Pseudotsuga menziesii) und Küstentanne (Abies grandis) in Abhängigkeit von der Nährstoffversorgung, Det forstlige Forsøgsvaesen i Danmark, 39: 1-82

Lavadinović, V. (1995): Variability of 29 Douglas-fir provenances in test plantations in Serbia with the aim of improving the introduction of this species. MSc Thesis. Faculty of Forestry. Belgrade. (In original: Lavadinović, V. (1995): Promenljivost 29 provenijencija duglazije u test kulturama Srbije u cilju unapređenja introdukcije ove vrste. Magistarski rad. Šmarski fakultet, Beograd)

Lavadinović, V. and Koprivica, M. (1996): Development of young Douglas-fir (Pseudotsuga taxifolia Britt.) stands of different provenances on beech sites in Serbia. IUFRO Conference "Modeling Regeneration Success and Early Growth of Forest stands" Proceedings. Copenhagen. 390-399 
Lavadinović, V. and Koprivica, M. (1999): Development of young Douglas-fir stands of different provenances on oak site in Serbia. IUFRO Conference "Empirical and Processbased Models for Forest Tree and Stand Growth Simulation" Proceedings. Lisboa. 231-241

Lavadinović, V. and Koprivica, M. (2000): Douglas-fir provenance tests in Serbia. XXI IUFRO World Congress "Forest and Society: Role of Research" Poster abstracts 3. Kuala Lumpur. 81

Lavadinović, V. and Isajev, V. (2005): Application of introduction as a method of tree breeding - the example of Douglas-fir (Pseudotsuga menziesi /Mirb./ Franco). Transilvania University of Brasov - Faculty of Silviculture and Forest Engineering. Brasov

Lavadinović, V. (2009): Genetic and ecological components of the variability of Douglasfir (Pseudotsuga menziesii /Mirb./ Franco) in test plantations in Serbia. PhD Thesis. University of Belgrade - Faculty of Forestry. Belgrade (In original: Lavadinović, V. (2009): Genetske i ekološke komponente varijabilnosti duglazije (Pseudotsuga menziesii /Mirb./ Franco) u provenijeničnim testovima na području Srbije. Doktorska disertacija. Univerzitet u Beogradu-Šumarski fakultet. Beograd)

Lavadinović, V., Isajev, V., Rakonjac, Lj. and Lučić, A. (2010): Influence of ecological characteristics of Douglas-fir test plantations in Serbia on trees survival. International conference "People, Forests and the Environment coexisting in Harmony" Book of abstracts. Casablanca. 42

Lavadinović, V., Miletić, Z., Isajev, V., Lučić, A. and Popović, V. (2012): Variability in contains of calcium in Douglas fir provenance needles originates from north America. International scientific conference „Forests in Future - Sustainable Use, Risks and Challenges“" Book of proceedings. Institute of Forestry. Belgrade. 407-411

Lavadinović, V., Miletić, Z. and Lavadinović, V. (2014): The phosphorus analyzes in needles of Canadian Douglas-fir provenances, Sustainable Forestry, 69-70: 25-32

Lavadinović, V., Miletić, Z. and Lavadinović, V. (2015): Variability of nitrogen and carbon contents in the needles of Canadian Douglas-fir provenances on two soil types in Serbia, Baltic Forestry, 21(2/41): 272-278

Lavadinović, V. S., Miletić, Z., Rakonjac, Lj. and Lavadinović, V. M. (2018): Magnesium concentration in the Canadian Douglas-fir needles of different provenances, Sustainable Forestry, 77-78: 45-55

Lavadinović, V., Rakonjac, Lj., Đunisijević-Bojović, D., Miletić, Z. and Jovanović, F. (2019): Variability of potassium concentration in the needles of Douglas-fir provenances, Bulletin of the Faculty of Forestry, 120: 97-116

Lavender, D. P. and Hermann, R. K. (2014): Douglas-fir: The genus Pseudotsuga. Oregon Forest Research Laboratory. Oregon State University. Corvallis

Nešković, M., Konjević, R. and Ćulafić, L. (2003): Plant physiology. NNK-International. Belgrade (In original: Nešković, M., Konjević, R., Ćulafić, L. (2003): Fiziologija biljaka. NNK-International. Beograd) 
Oljača, R., Krstić, B. and Pajević, S. (2006): Plant physiology. University of Banja Luka Faculty of Forestry. Banja Luka (In original: Oljača, R., Krstić, B., Pajević, S. (2006): Fiziologija biljaka. Šmarski fakultet Univerziteta u Banjoj Luci. Banja Luka)

Popović, V., Lavadinović, V., Bjelanović, I. and Lavadinović, V. (2013): Dependence of Douglas-fir mean height on geographic origin of Canadian provenances in seedling nursery, Ekológia, Bratislava, 32(3): 328-334

Spiecker, H., Lindner, M. and Schuler, J. (2019): Douglas-fir - an option for Europe. What Science Can Tell Us 9. European Forest Institute. Joensuu

Timmis, R. (1974): Effect of nutrient stress on growth, bud set, and hardiness in Douglasfir seedlings. North American Containerized forest Tree Seedling Symposium Proceedings. Publication 68. Great Plains Agricultural Council. Denver. 187-193

Wang, M., Zheng, Q., Shen, Q. and Guo, S. (2013): The critical role of potassium in plant stress response, International Journal of Molecular Sciences, 14(4): 7370-7390

\title{
VARIABILITY OF POTASSIUM CONTENT IN THE NEEDLES OF DOUGLAS-FIR PROVENANCES OF CANADIAN ORIGIN
}

\author{
Filip JOVANOVIĆ, Vera LAVADINOVIĆ, Ljubinko RAKONJAC, \\ Snežana STAJIĆ, Zoran MILETIĆ
}

\section{Summary}

Douglas-fir [Pseudotsuga menziesii (Mirb.) Franco, fam. Pinaceae] is a very tall and fast-growing conifer native to North America. Since it comes from a wide natural range of distribution, the provenance selection is a necessary step in the confirmation of its genetic potentials after introduction into new habitats. The genetic potentials of trees could be tested by the analysis of their physiological properties. Since potassium has considerable importance in the physiological processes of plants, this paper presents an analysis of the variability of potassium content in the needles of different Douglas-fir provenances.

The study included 14 Douglas-fir provenances from Canadian sites of different geographical latitudes, longitudes, and altitudes (Table 1). In order to test their adaptability to the new climatic and environmental conditions, provenance trial plantations have been established on two sites and two soil types in Belgrade, Serbia (Arboretum of the Faculty of Forestry, and Sremčica nursery). The potassium content in young needles of each analyzed Douglas-fir provenance was determined by a laboratory ash analysis. Statistical analysis of the obtained data was conducted using the Z-test.

The results show there are no significant differences in the uptake of potassium between the provenances raised on vertisol $(0.71 \%)$ and those raised on eutric cambisol $(0.72 \%)$. Provenances 1,2 and 7 had normal potassium contents in their needles, while the provenances 10 and 13 were low or deficient in this nutrient (Table 2; Graph 1). Since the environmental conditions that have a significant impact on nutrient uptake in plants had been similar on the experimental sites, it may be argued that the detected variability was a result of the genetic traits of the analyzed provenances. The highest potassium content was found in the provenances 1, 2 and 7, thus they may represent superior provenances for the uptake and accumulation of this nutrient. Further studies should show whether there are positive correlations between potassium content and other provenance properties (such as physiological vitality and resistance to diseases and air pollution). 
The potassium content in tissues of Douglas-fir is one of the factors that affect the resistance of trees to stress factors (such as cold and drought) and it could determine the future selective application of suitable provenances for certain habitats in forestry practice. Thus, the results of this study may contribute to a better selection of provenances suitable for the introduction of Douglas-fir to Serbia.

\title{
VARIJABILNOST SADRŽAJA KALIJUMA U ČETINAMA KANADSKIH PROVENIJENCIJA DUGLAZIJE
}

\author{
Filip JOVANOVIĆ, Vera LAVADINOVIĆ, Ljubinko RAKONJAC, \\ Snežana STAJIĆ, Zoran MILETIĆ
}

\section{Rezime}

Duglazija [Pseudotsuga menziesii (Mirb.) Franco, fam. Pinaceae] je visoko i brzorastuće četinarsko drvo, poreklom iz Severne Amerike. Budući da ima široko prirodno rasprostranjenje, odabir provenijencija predstavlja neophodan korak u potvrđivanju njenih genetičkih potencijala nakon unošenja u nova staništa. Genetički potencijali drveća mogu se ispitati analizom njihovih fizioloških svojstava. Kako kalijum igra vrlo važnu ulogu u fiziološkim procesima biljaka, u ovom radu su predstavljeni rezultati analize varijabilnosti sadržaja kalijuma u četinama različitih provenijencija duglazije.

Istraživanjem je obuhvaćeno 14 provenijencija duglazije, poreklom sa kanadskih lokaliteta različitih geografskih dužina, geografskih širina i nadmorskih visina (Tabela 1). Da bi se proverila njihova prilagođenost novim klimatskim i stanišnim prilikama, osnovane su test kulture na dva lokaliteta (i dva tipa zemljišta) na području Beograda (u Arboretumu Šumarskog fakulteta i Rasadniku „Sremčica” - „Srbija šume”). Sadržaj kalijuma u mladim četinama svake ispitivane provenijencije duglazije određen je analizom pepela. Statistička obrada dobijenih podataka je izvedena $Z$-testom.

Rezultati pokazuju da u usvajanju kalijuma nema značajnih razlika između onih provenijencija koje su odgajene na smonici $(0,71 \%)$ i onih odgajenih na gajnjači $(0,72 \%)$. U četinama provenijencija 1, 2 i 7 zabeležen je normalan sadržaj kalijuma, dok u četinama provenijencija 10 i 13 primećen je nizak sadržaj ili nedostatak ovog elementa (Tabela 2; Grafikon 1). Kako su uslovi sredine koji su značajni za usvajanje elemenata ishrane kod biljaka bili međusobno vrlo slični na eksperimentalnim poljima, može se pretpostaviti da je utvrđena varijabilnost rezultat genetičkih karakteristika ispitivanih provenijencija. Najveća vrednost sadržaja kalijuma je bila utvrđena za provenijencije 1, 2 i 7, te je moguće da one predstavljaju superiorne provenijencije za usvajanje i akumulaciju ovog elementa. Buduća istraživanja će pokazati da li postoji pozitivna zavisnost između sadržaja kalijuma i drugih karakteristika provenijencija (npr., vitalnost i otpornost na bolesti i zagađenje vazduha). Sadržaj kalijuma u tkivima duglazije je jedan od faktora koji utiču na otpornost stabala na faktore stresa (npr., mraz i suša), što može opredeliti buduću selektivnu primenu provenijencija odgovarajućih za određena staništa u šumarskoj praksi. Stoga, rezultati ovog istraživanja mogu doprineti boljem odabiru odgovarajućih provenijencija za introdukciju duglazije u Srbiju. 